Practices (ACIP) and the Hospital Infection Control Practices Advisory Committee (HICPAC). MMWR 1997;46(RR-18):11-13,25-26.

5. Tennenberg AM, Brassard JE, Van Lieu J, Drusin LM. Varicella vaccination for healthcare workers at a university hospital: an analysis of costs and benefits. Infect Control Hosp Epidemiol 1997;18:405-411.

6. Nettleman MD, Schmid MS. Controlling varicella in the healthcare setting: the cost effectiveness of using varicella vaccine in healthcare workers. Infect Control Hosp Epidemiol 1997;18:504-508.

7. Weber DJ, Rutala WA, Hamilton H. Prevention and control of varicellazoster infections in healthcare facilities. Infect Control Hosp Epidemiol 1996;17:694-705.

8. Wasmuth EH, Miller WJ. Sensitive enzyme-linked immunosorbent assay for antibody to varicella-zoster virus using purified VZV glycoprotein antigen. J Med Virol 1990;32:189-193.

9. Varivax package insert. Merck \& Co, Inc: West Point, PA; 1995.

10. Landry ML, Ferguson D. Comparison of latex agglutination test with enzyme-linked immunosorbent assay for detection of antibody to varicella-zoster virus. J Clin Microbiol 1993;31:3031-3033.

11. Krah DL. Assays for antibodies to varicella-zoster virus. Infect Dis Clin North Am 1996;10:507-527.
12. VZVScan package insert. Becton-Dickson: Meylan, France; 1995.

13. Gershon AA, Steinberg SP, LaRussa P, Ferrara A, Hammerschlag M, Gelb L. Immunization of healthy adults with live attenuated varicella vaccine. J Infect Dis 1988;158:132-137.

14. Varicella vaccine. Medical Letter 1995;37:55-57.

15. Kuter BJ, Ngai A, Patterson CM, Staehle BO, Cho I, Matthews H, et al. Safety, tolerability, and immunogenicity of two regimens of $\mathrm{Oka} /$ Merck varicella vaccine (Varivax) in healthy adolescents and adults. Oka/Merck Varicella Vaccine Study Group. Vaccine 1995;13: 967-972.

16. Johnson CE, Stancin T, Fattlar D, Rome LP, Kumar ML. A long-term prospective study of varicella vaccine in healthy children. Pediatrics 1997;100:761-766.

17. Zerboni L, Nader S, Aoki K, Arvin AM. Analysis of the persistence of humoral and cellular immunity in children and adults immunized with varicella vaccine. $J$ Infect $D$ is 1998;177:1701-1704.

18. Preblud SR. Nosocomial varicella: worth preventing, but how? Am J Public Health 1988;78:13-15.

19. Gershon AA, LaRusssa P, Hardy I, Steinberg S, Silverstein S. Varicella vaccine: the American experience.J Infect Dis 1992;166(suppl 1):S63-S68.

\title{
Hygienic Practices of Anesthetists in the United Kingdom
}

\section{Gina Pugliese, RN, MS}

Martin S. Favero, $\mathbf{P h D}$

Dr. el Mikatti and colleagues from Withington Hospital, United Kingdom, conducted a survey to assess hygienic precautions taken by anesthesiologists. Questionnaires were distributed to all 213 consultant anesthetists in the northwest region of the United Kingdom, with a response rate of $68 \%$.
Face masks and gloves were always used by $35 \%$ and $15 \%$, respectively; only $36 \%$ washed their hands between cases. A high proportion of anesthetists continue to administer anesthesia despite suffering from respiratory (94\%), gastrointestinal (42.9\%), or herpes simplex $(32.6 \%)$ infections. The anesthetic breathing system was changed at the end of each day or following a high-risk case by $33 \%$ of the respondents, whereas just over $25 \%$ changed it following a known infected case. Bacterial filters were used by $17 \%$ and changed after each case by $7 \%$. The authors concluded that, although anesthetists are well aware of proper hygienic practices, their performance falls short of accepted recommendations.

FROM: el Mikatti N, Dillon P, Healy TE. Hygienic practices of consultant anaesthetists: a survey in the northwest region of the UK. Anaesthesia 1999;54:13-18.

\section{Inactivation of Cryptosporidium parvum Oocyst}

\section{Gina Pugliese, RN, MS Martin S. Favero, PhD}

Cryptosporidium parvum is a common cause of self-limited gastroenteritis in the normal host but may cause severe disease in immunocompromised persons. Person-to-person transmission has been well documented in households, child-care centers, and hospitals. Because contaminated environmental surfaces and medical devices such as endoscopes may play a role in disease transmission, Barbee and coinvestigators from the University of North Carolina studied the susceptibility of $C$ parvum to chemical agents commonly used for disinfection of medical devices, as well as the efficacy of sterilization processes. Seven disinfectants were studied at their use dilution using a suspension test. Antimicrobial activity was assessed with the use of a cell infectivity assay.

All sterilization processes tested (steam, ethylene oxide, hydrogen peroxide gas plasma [Sterrad 100, Advanced Sterilization Products, Irvine, CA]), inactivated 3 logs or greater of $C$ parvum. The only liquid disinfectant or sterilant able to inactivate greater than 3 logs of $C$ parvum was $6 \%$ and $7.5 \%$ hydrogen peroxide. Agents that did not completely inactivate $C$ parvum included hydrogen peroxide at lower concentrations or exposure times, peracetic acid, sodium hypochlorite, a pheno- lic, a quaternary ammonium compound, $2 \%$ glutaraldehyde, and orthophthalaldehyde.

The authors concluded that most high-level disinfectants used on endoscopes have limited efficacy against $C$ parvum. However, the infectivity of $C$ parvum on dry surfaces decreases rapidly. Therefore, current cleaning and high-level disinfection guidelines are adequate to prevent nosocomial transmission of $C$ parvum by means of endoscopes.

FROM: Barbee SL, Weber DJ, Sobsey MD, Rutala WA. Inactivation of Cryptosporidium parvum oocyst infectivity by disinfection and sterilization processes. Gastrointest Endosc 1999;49:605-611. 